medRxiv preprint doi: https://doi.org/10.1101/2020.06.17.20133504; this version posted June 20, 2020. The copyright holder for this preprint (which was not certified by peer review) is the author/funder, who has granted medRxiv a license to display the preprint in perpetuity.

It is made available under a CC-BY 4.0 International license .

\title{
Risk of SARS-CoV-2 infection from contaminated water systems
}

3 Jamie Shutler $^{{ }^{*}}$, Krzysztof Zaraska ${ }^{2}$, Tom Holding ${ }^{1}$, Monika Machnik $^{2}$, Kiranmai Uppuluri ${ }^{2}$, Ian Ashton ${ }^{1}$, Łukasz Migdał $^{3}$, Ravinder Dahiya ${ }^{4}$

${ }^{1}$ University of Exeter, Penryn campus, Cornwall, UK.

2 Łukasiewicz - Institute of Electron Technology, Poland.

$8{ }^{3}$ University of Agriculture in Krakow, Poland.

$9{ }^{4}$ Bendable Electronics and Sensing Technologies (BEST) Group, University of Glasgow, 10 Glasgow, UK.

11 * Corresponding author email address j.d.shutler@exeter.ac.uk

\section{Abstract}

Following the outbreak of severe acute respiratory syndrome coronavirus (SARS-CoV-2)

in China, airborne water droplets (aerosols) have been identified as the main transmission route, although other transmission routes are likely to exist. We quantify SARS-CoV-2 virus survivability within water and the risk of infection posed by faecal contaminated water within 39 countries. We identify that the virus can remain stable within water for up to 25 days, and country specific relative risk of infection posed by faecal contaminated water is related to the environment. Faecal contaminated rivers, waterways and water systems within countries with high infection rates can provide infectious doses $>100$ copies within $100 \mathrm{ml}$ of water. The implications for freshwater systems, the coastal marine environment and virus resurgence are discussed. 
medRxiv preprint doi: https://doi.org/10.1101/2020.06.17.20133504; this version posted June 20, 2020. The copyright holder for this preprint (which was not certified by peer review) is the author/funder, who has granted medRxiv a license to display the preprint in perpetuity.

It is made available under a CC-BY 4.0 International license .

\section{Introduction}

The outbreak of the severe acute respiratory syndrome coronavirus (SARS-CoV-2) began in Wuhan province, China in December 2019 and has now spread throughout the world with about 6 million cases confirmed globally within 214 countries and territories. Water aerosols originating from individuals infected by SARS-CoV-2 are considered a major pathway for infection ${ }^{1}$, and the virus has been shown to remain stable in saline solution ${ }^{2}$ and under varying environmental conditions ${ }^{3}$. Viral shedding in faeces of viable SARSCoV-2 virus is documented (eg ${ }^{4}$ ) and SARS-CoV-2 ribonucleic acid (RNA) has been detected in the shed faeces of both symptomatic and asymptomatic children and adults $\left(\mathrm{eg}^{5}\right)$; with potentially $43 \%$ of infections being asymptomatic and unreported ${ }^{6}$.

Human viral pathogens that can be transmitted by water that pose moderate to high health significance as defined by the WHO include adenovirus, astrovirus, hepatitis A and E, rotavirus, norovirus and other enteroviruses. The survival of the large family of coronavirus in water systems has been highlighted ${ }^{7}$, and viral loads within untreated wastewater, consistent with population infection rates, have been identified ${ }^{8}$. While evidence for SARS CoV-2 is limited, other human coronaviruses are documented to survive in wastewater effluent ${ }^{9}$, with colder water temperature likely to increase survival considerably ${ }^{3}$. Collectively this evidence suggests that SARS-CoV-2 virus can survive within water and the viral loads within untreated sewage effluent are likely high in countries of high infection rates, a portion of which is viable virus, and therefore water contaminated with sewage provides a potential faecal-oral transmission route $\left(\mathrm{eg}^{10}\right)$.

Sewage can directly enter natural water systems due to combined sewer overflow events and sewage exfiltration from pipes (eg ${ }^{11}$ ) unexpected failure of water treatment systems or a complete lack of water treatment infrastructure, providing a pathway for onward 
medRxiv preprint doi: https://doi.org/10.1101/2020.06.17.20133504; this version posted June 20, 2020. The copyright holder for this preprint (which was not certified by peer review) is the author/funder, who has granted medRxiv a license to display the preprint in perpetuity.

It is made available under a CC-BY 4.0 International license .

53 transmission. For example, during the current pandemic large sewage spills, flooding

54 dwellings and community spaces, have occurred in America (within Georgia, Florida and New York) and Spain (Andalucia), while temporary settlements (eg shanty towns, favelas

or bustees) and refugee camps are less likely to have safe sanitation systems. Within

these settings, this water system pathway could enable viral infection to humans or other susceptible animals via water ingestion or through filtering of water during feeding.

The highly skewed distribution of infected patient viral loads observed ${ }^{12}$ contain the effects of super spreaders, where single individuals can be responsible for the majority of the viral loading. This viral distribution means that sewage originating from populations that contain super spreaders will contain very high viral loads, even though the majority of the population contribute relatively low viral loadings.

Considering the above, we identify the survivability of SARS-CoV-2 within water systems using published in vitro study data ${ }^{3}$. We then used an established 'down the drain' pollution analysis to calculate the dilution in rivers ${ }^{13}$, combined with our empirical virus survivability model, to calculate of the relative risk posed to humans by sewage spills within 39 countries. Results using infection numbers on May 032020 for 21 countries, where inland water temperatures were available, identify viable waterborne virus concentrations that, if faecal contamination had occurred, would result in a high probability of infection. The implications of these findings for waterborne virus transmission to humans and animals are discussed and recommendations for reducing risk of infection are given.

\section{Results}

Exponential temperature driven survivability identifies that the virus can remain stable and above detection limits for up to 25 days (figure $1 \mathrm{a}$ ). The relative risk, the normalized 
medRxiv preprint doi: https://doi.org/10.1101/2020.06.17.20133504; this version posted June 20, 2020. The copyright holder for this preprint (which was not certified by peer review) is the author/funder, who has granted medRxiv a license to display the preprint in perpetuity.

It is made available under a CC-BY 4.0 International license .

country comparable risk associated with a sewage spill after dilution within rivers (figure $1 \mathrm{~b}, 1 \mathrm{c})$ is dependent upon domestic water usage and riverine dilution, where dilution is dependent upon geographical location, relief and weather. Countries with lowest relative risk are those with both high domestic water usage and high dilution (eg Canada, Norway and Venezuela). Highest relative risk results from a combination of low to medium domestic water usage and low dilution (eg Morocco, Spain, Germany). Translating these results to the proportion of the population infected within 21 countries on May 032020 identifies the estimated upper and lower limit of viable waterborne virus concentration within the first 24 hours, assuming that a spill occurred (figure 2; uncertainty on the viable virus concentration is $\pm 68 \%$ copies $\mathrm{L}^{-1}$ ). Absolute concentrations are higher and will exist for longer within countries with a combination of higher relative risk, colder water and high population infection rates. Assuming infection requires a dose of 100 copies, then a person within the 3 countries with the highest concentrations (Spain, UK, Morocco) who within 24 hours of a spill ingests $100 \mathrm{ml}$ of the contaminated water could receive a total dose $>468$ copies resulting in a high probability of infection (table 1; full dosage range across all cases is 46 to 3080 copies). $100 \mathrm{ml}$ is the equivalent of 1 to 2 mouthfuls and swimmers can swallow up to $280 \mathrm{ml}$ in a 45 minute swim ${ }^{14}$. The combination of figure $1 \mathrm{a}$ and figure $2 a$ can be used to understand the viable virus concentration after the first 24 hours. The water temperature-controlled virus survivability means that concentrations reduce quickly in Morocco within 24 hours of a spill, whereas the concentrations remain for longer in Spain and the UK where water temperatures are lower (table 1; Figure 2a). 
medRxiv preprint doi: https://doi.org/10.1101/2020.06.17.20133504; this version posted June 20, 2020. The copyright holder for this preprint (which was not certified by peer review) is the author/funder, who has granted medRxiv a license to display the preprint in perpetuity.

It is made available under a CC-BY 4.0 International license.

105 Table 1 Viable virus concentration results for the 3 countries for the 3 May 2020 assuming a spill occurred. Median dilution (DF) along with middle* and high ${ }^{\$}$ viable to unviable viral

107 ratio (I) results are given to provide a reasonable range of the concentrations within the

108 first 24 hours. ${ }^{\&}$ Low DF and high I results enable the extreme range of concentrations to

109 be estimated. Viral survival rates after 24 and 48 hours show how the viable viral

110 concentrations reduce due to temperature driven die off.

\begin{tabular}{|c|c|c|c|c|c|c|c|}
\hline Country & Code & $\begin{array}{l}{ }^{*} \mathrm{I}=1 \% \text {, } \\
\text { median } \mathrm{DF} \text {, } \\
\text { copies } \mathrm{L}^{-1}\end{array}$ & $\begin{array}{l}\$ \mathrm{I}=10 \% \text {, } \\
\text { median } \mathrm{DF} \text {, } \\
\text { copies } \mathrm{L}^{-1}\end{array}$ & $\begin{array}{l}\text { \& } \mathrm{I}=10 \%, \\
\text { low DF, } \\
\text { copies } \mathrm{L}^{-1}\end{array}$ & $\begin{array}{l}100 \mathrm{ml} \text { dose for } \\
\text { case } \$ \text { and total } \\
\text { range, copies }\end{array}$ & $\begin{array}{l}24 \text { hour } \\
\text { survival } \\
, \%\end{array}$ & $\begin{array}{l}48 \text { hour } \\
\text { survival } \\
\text {, \% }\end{array}$ \\
\hline Spain & SPA & 632 & 6325 & 6325 & $633\left(63^{*}\right.$ to $\left.633^{8}\right)$ & 67 & 45 \\
\hline UK & GBR & 468 & 4682 & 30792 & $468\left(47^{*}\right.$ to $\left.3080^{\alpha}\right)$ & 72 & 52 \\
\hline Morocco & MAR & 459 & 4595 & 25255 & $459\left(46^{*}\right.$ to $\left.2526^{*}\right)$ & 38 & 15 \\
\hline
\end{tabular}


medRxiv preprint doi: https://doi.org/10.1101/2020.06.17.20133504; this version posted June 20, 2020. The copyright holder for this preprint (which was not certified by peer review) is the author/funder, who has granted medRxiv a license to display the preprint in perpetuity.

It is made available under a CC-BY 4.0 International license .

a

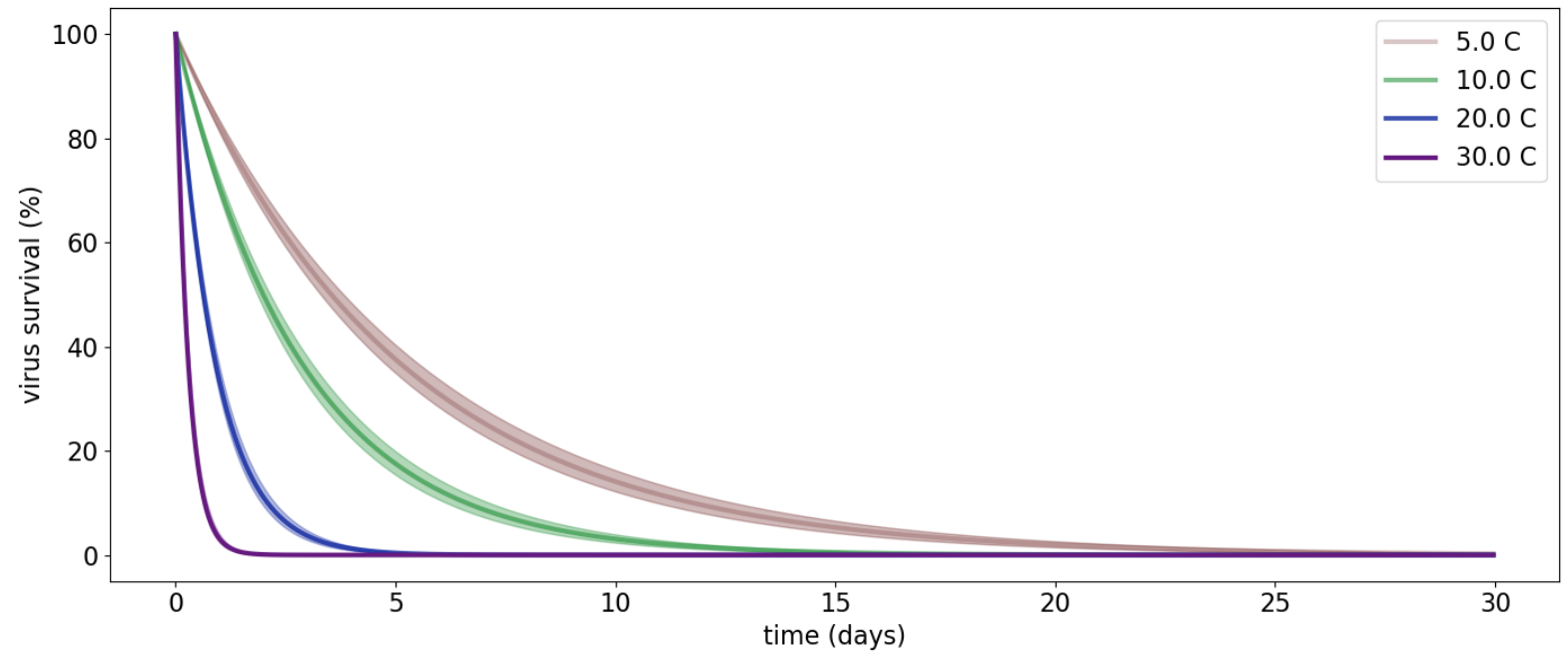

b

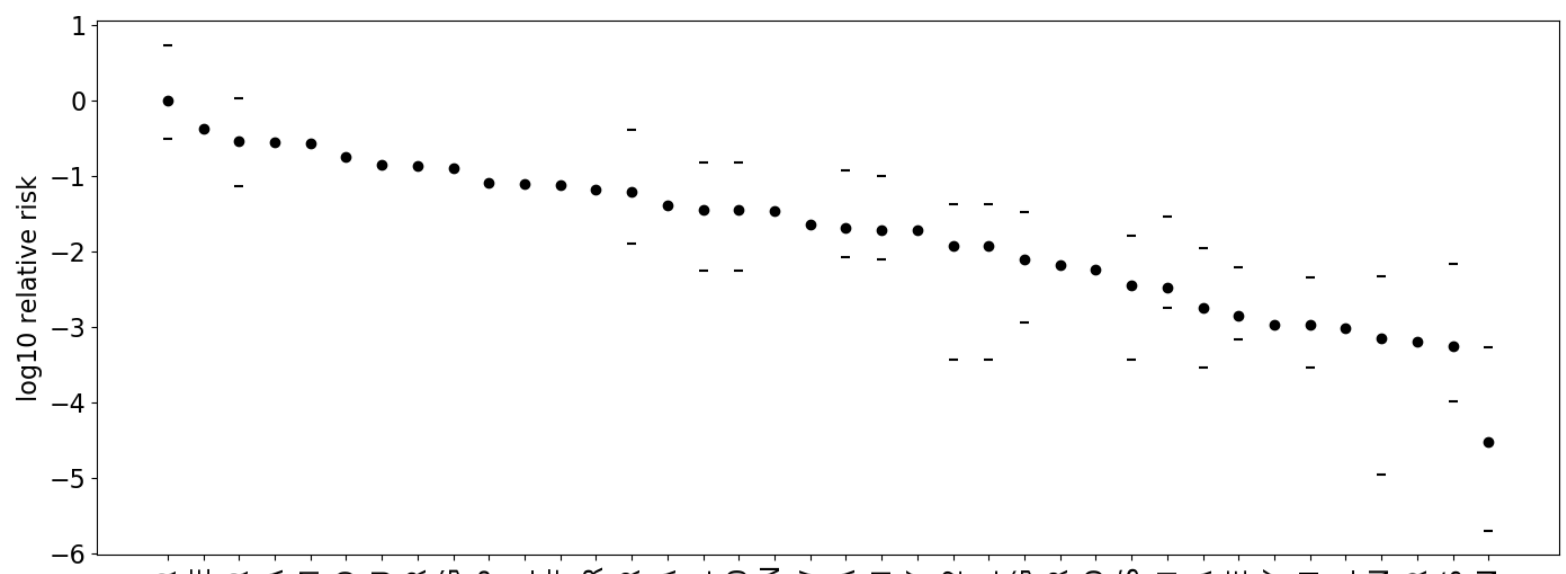

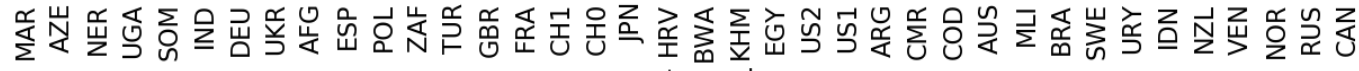
country code

C
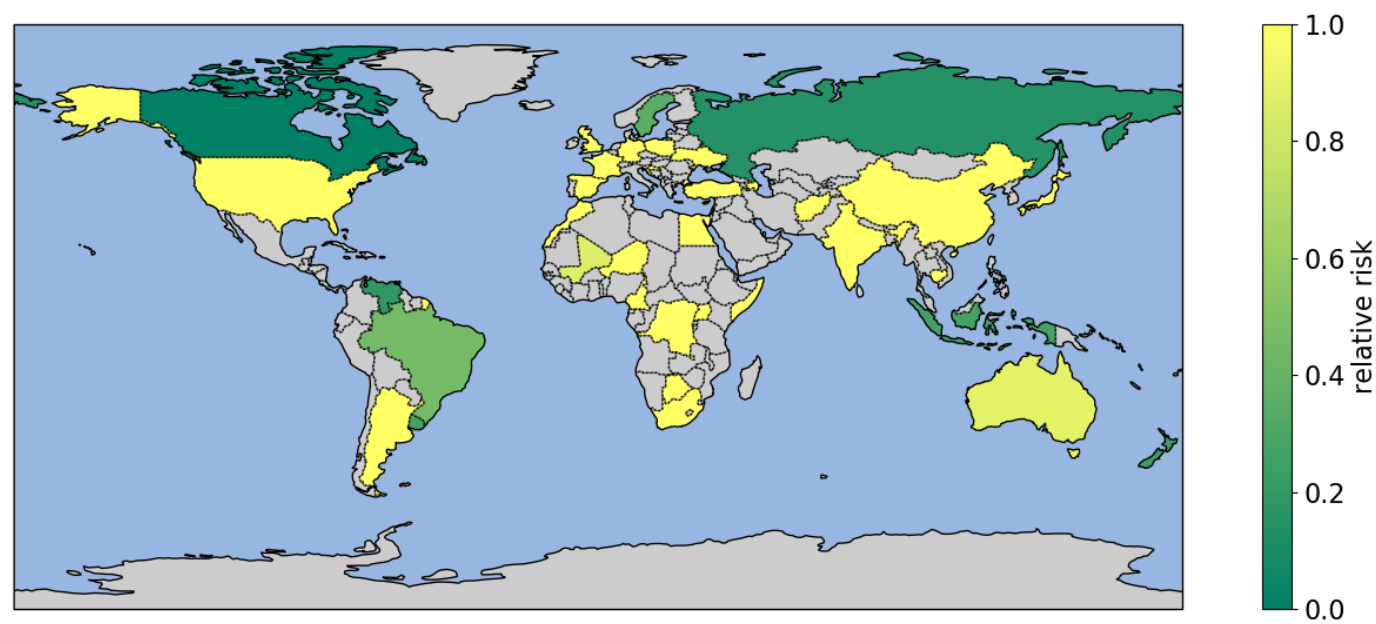

Figure 1 Virus survivability within water and relative risk posed by sewage spills into rivers for 39 countries; a) modelled temperature survivability. Shaded areas show the temperature dependent uncertainties; b) $\log _{10}$ relative risk covering the range of 0.001 to 1.0 ; circles are median values, horizontal lines are $25^{\text {th }}$ and $75^{\text {th }}$ percentiles due to dilution factors from ${ }^{13}$ and c) countries where relative risk has been calculated with relative risk as a linear scale; grey signifies a country not included. 
medRxiv preprint doi: https://doi.org/10.1101/2020.06.17.20133504; this version posted June 20, 2020. The copyright holder for this preprint (which was not certified by peer review) is the author/funder, who has granted medRxiv a license to display the preprint in perpetuity.

a
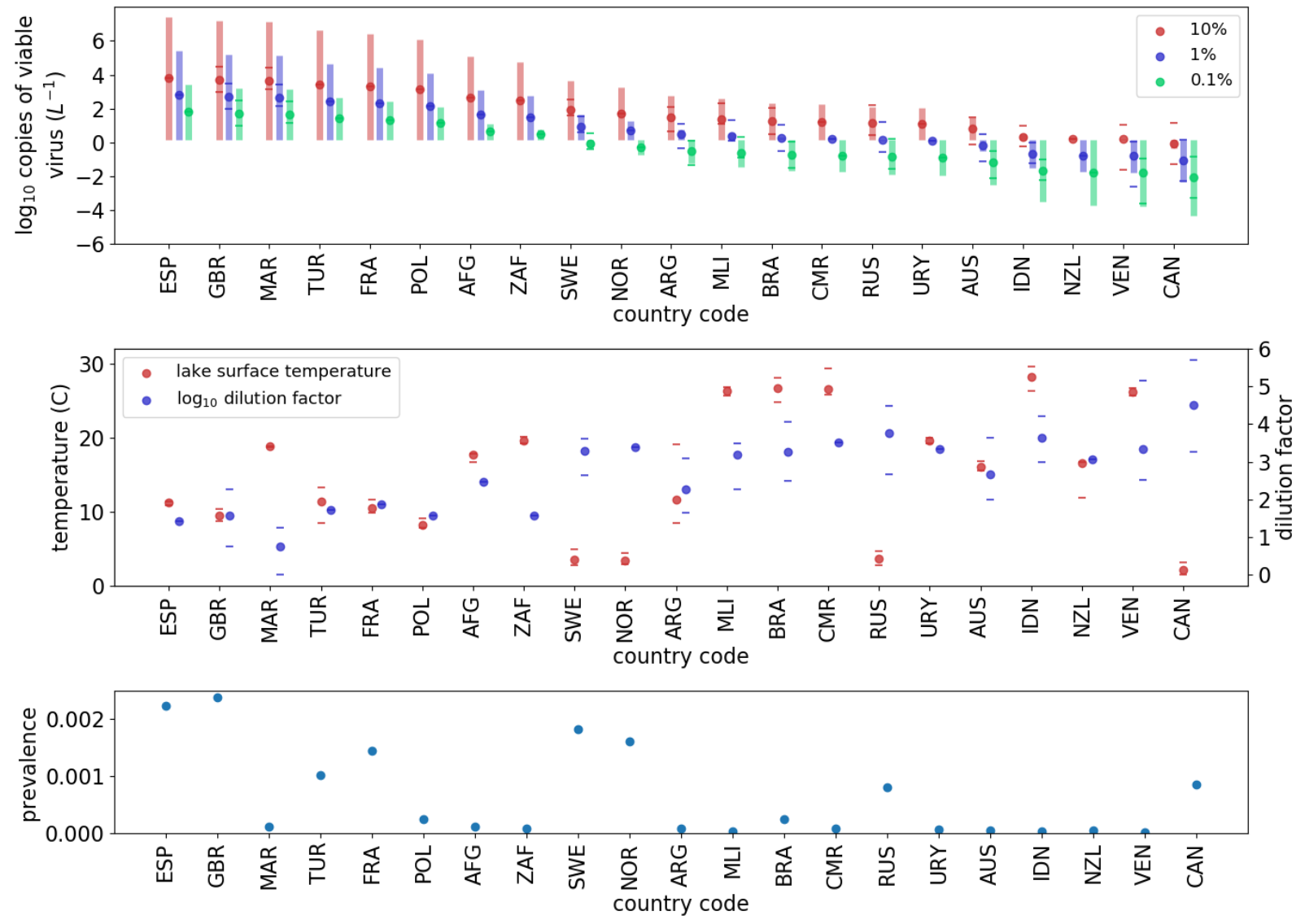

b
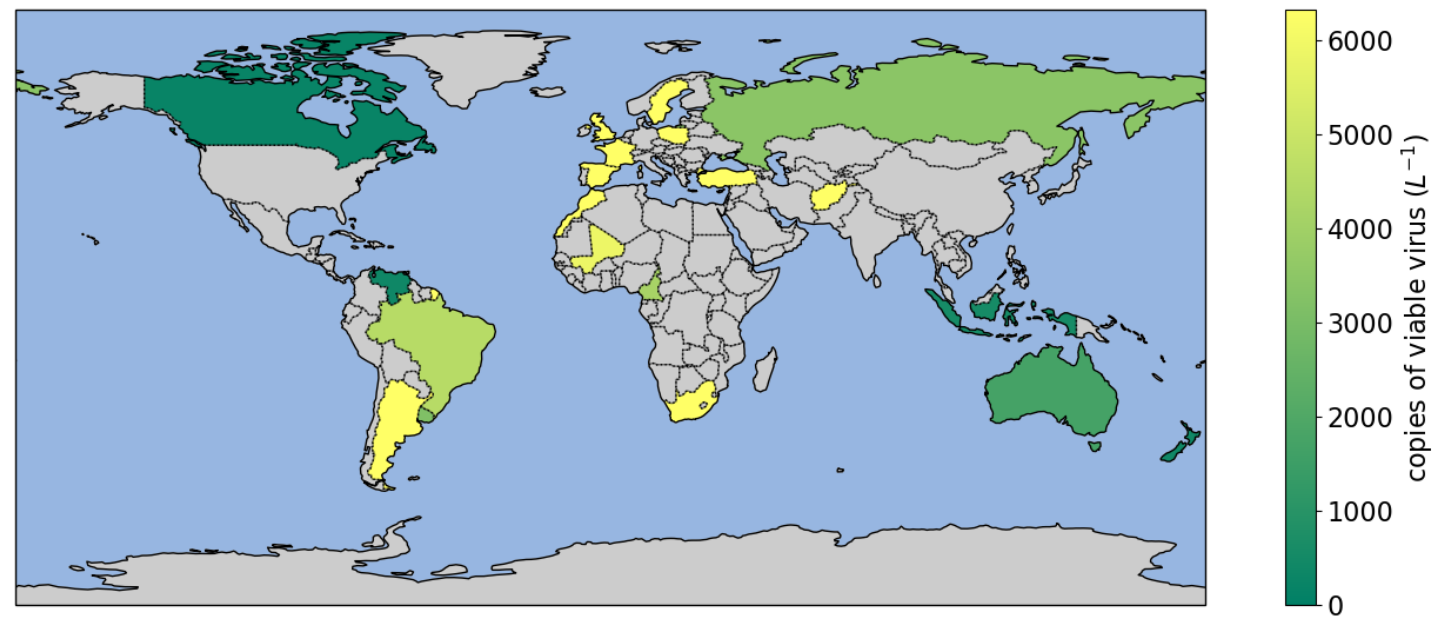

Figure 2 Estimate of absolute viable viral concentration within inland waters on the May 03 2020 for 21 countries assuming a sewage spill has occurred. a) absolute viable viral concentrations in $\log _{10}$ copies. Circles are median, horizontal lines are $25^{\text {th }}$ and $75^{\text {th }}$ percentiles due to dilution factors from ${ }^{13}$; shaded uncertainty bars are $\pm 68 \%$ copies $\mathrm{L}^{-1}$. Results are shown for three possible ratios of viable virus to viral genome copies $(10 \%, 1 \%$ and $0.1 \%$ ) and b) countries where viable viral loads have been calculated. Grey signifies a country not included; viral concentrations are presented as a linear scale in copies of viable virus. 
medRxiv preprint doi: https://doi.org/10.1101/2020.06.17.20133504; this version posted June 20, 2020. The copyright holder for this preprint (which was not certified by peer review) is the author/funder, who has granted medRxiv a license to display the preprint in perpetuity.

It is made available under a CC-BY 4.0 International license .

\section{Discussion}

115 The detection of SARS-CoV-2 virus in the aquatic environment ${ }^{15}$ does not necessarily 116 translate into the presence of viable virus. To estimate the number of viable (infectious)

117 virus copies, the proportion of infectious viruses in sewage must be known. The presence 118 of infectious virus in stool samples has been demonstrated ${ }^{4}$, but there is a lack of 119 quantitative data on this ratio for SARS-CoV-2 in stool. We instead used literature on the 120 number of infectious adenovirus copies in sewage $\left(\mathrm{eg}^{16}\right)$ and wastewater discharge into 121 rivers ${ }^{17}$ to select high $\left(10^{-1}\right)$ medium $\left(10^{-2}\right)$ and low $\left(10^{-3}\right)$ estimates for the ratio of 122 infectious virus to genome copies to infectious viruses. We note that adenoviruses are 123 known to be particularly resilient, and therefore likely to represent an upper estimate, but 124 also that our selected range is consistent with the $10^{-3}$ value used elsewhere for assessing 125 viral risk in water systems (eg ${ }^{14}$ ), including one assessment for SARS CoV-2 transmission 126 risk to wastewater workers ${ }^{18}$.

128 The temperature dependent survivability means that it is likely that the risk posed by 129 wastewater will increase during winter months as the sewage temperature will be lower 130 enabling longer viral survival, but temperature history and age of the sewage will be 131 needed to fully understand any detected viral loads. SARS-CoV-2 infection to, and spread 132 between, domestic cats has occurred due to similarities between human and some animal 133 angiotensin converting enzyme 2 (ACE2) gene ${ }^{20}$. Increased animal foraging can occur 134 downstream from water treatment facilities, relative to upstream, highlighting possible risk 135 of some riparian wildlife infection if feeding occurs after a spill.

138 It is possible that SARS-CoV-2 survivability and transport within rivers could impact 139 drinking water supplies in countries where rivers or reservoirs are the primary drinking 
medRxiv preprint doi: https://doi.org/10.1101/2020.06.17.20133504; this version posted June 20, 2020. The copyright holder for this preprint (which was not certified by peer review) is the author/funder, who has granted medRxiv a license to display the preprint in perpetuity.

It is made available under a CC-BY 4.0 International license .

140 water sources and where large populations, with little or no sewage treatment, exist close

141 to the water source, such as within refugee camps or shanty towns. Riverine enteric virus 142 transport and catchment accumulation can occur for common viruses $\left(\mathrm{eg}^{21}\right)$ and under

143 stratified conditions it would be possible for a river plume to enter a reservoir and

144 subsequently exit through the reservoir outlet without mixing with the main body of water.

145 Filtering of water, followed by ultraviolet disinfection or chlorination are the recommended 146 approaches for virus removal from drinking water sources ${ }^{22}$. Filtering is normally used to 147 remove large particulates. The effective ultraviolet dose for SARS-CoV-2 disinfection 148 appears highly variable and dependent upon the surface to which the virus is attached ${ }^{23}$. 149 The upper dosage value of 1 Joule $(\mathrm{J}) \mathrm{cm}^{-2}$ to ensure effective ultraviolet disinfection of 150 SARS-CoV-2 ${ }^{23}$ is an order of magnitude larger than that typically used $\left(\sim 40\right.$ to $90 \mathrm{~mJ} \mathrm{~cm}^{-}$ $152^{2}$ ) for low volume domestic drinking water treatment. The World Health Organization 152 (WHO) guidelines state that effective chlorination disinfection occurs at residual chlorine 153 concentrations of $\geq 0.5 \mathrm{mg} \mathrm{L}^{-1} 22$, which matches the minimum needed to deactivate 154 SARS-CoV-1 ${ }^{24}$. However, the actual chlorine dosage used for water treatment can vary, 155 based on country, region, water origin and infrastructure (eg UK guidelines are 156 concentrations of 0.2 to $0.5 \mathrm{mg} \mathrm{L}^{-1}$ ). Collectively this means that if a drinking water source 157 was to become infected with SARS-CoV-2 the standard virus removal and disinfection 158 approaches of ultraviolet exposure and chlorination may not reduce the virus below 159 detectable limits. Reviewing of regional or countrywide drinking water processing 160 approaches is recommended to reduce the potential for SARS-CoV-2 surviving through 161 drinking water processing systems. Boiling of drinking water will result in the virus being 162 deactivated ${ }^{22}$. Refrigerated food that becomes contaminated (eg through washing or 163 handling) could remain infectious for up to 25 days. 
medRxiv preprint doi: https://doi.org/10.1101/2020.06.17.20133504; this version posted June 20, 2020. The copyright holder for this preprint (which was not certified by peer review) is the author/funder, who has granted medRxiv a license to display the preprint in perpetuity.

It is made available under a CC-BY 4.0 International license.

\section{Implications for the marine environment}

167 The virus remains stable over a range of $\mathrm{pH}^{3}$ and in sterile saline solution at low temperatures $^{2}$, so it is possible that there is no significant difference in virus temporal survival and infection risk between freshwater and seawater, and SARS-CoV-2 has already been identified within seawater, originating from untreated wastewater ${ }^{7}$.

171 Bioaccumulation of the SARS-CoV-2 virus by molluscs and other aquatic organisms may

172 occur as bivalves are known to accumulate waterborne viruses including hepatitis, norovirus and avian influenza ${ }^{25}$.

Multiple cetaceans have very high ACE2 similarity to humans making them susceptible to SARS-CoV-2 infection including harbor porpoises, bottle nosed dolphins, minke whales, orca and pilot whales ${ }^{20}$. Of particular concern are whales whose throats are exposed to large volumes of water during feeding and who visit coastlines for prey that are known to accumulate around sewage outfalls, such as minke whales feeding on mackerel or orca feeding on chinook salmon. In these instances, the animal could be exposed to a large viral dose, even if the virus is only present within the water in low concentrations. For 182 example, if the riverine viral concentration is low at 1 copie $\mathrm{ml}^{-1}$, which is undetectable by PCR (detection limit is $>100$ copies $\mathrm{ml}^{-1}$ ), then a medium sized whale filtering water during feeding could receive repeated doses of 5.65 million copies every second (see methods for calculation). A seafood market is among the suspected sources for the origin of the SARS-CoV-2 virus, so any viral transmission from land to sea may be a circular process.

\section{Conclusions}

189 Natural water systems are likely able to act as a transmission pathway for SARS-CoV-2 190 which poses a threat to human infection. The analysis suggests that public interactions 191 with rivers and coastal waters following wastewater spills should be minimized to reduce 
medRxiv preprint doi: https://doi.org/10.1101/2020.06.17.20133504; this version posted June 20, 2020. The copyright holder for this preprint (which was not certified by peer review) is the author/funder, who has granted medRxiv a license to display the preprint in perpetuity.

It is made available under a CC-BY 4.0 International license .

192 the risk of infection. New volume integrating viral detection methods are needed to ensure

193 the safety of water systems. While the primary risk associated with the current COVID-19

194 outbreak appears to be human-to-human transmission of SARS-CoV-2, this work supports

195 the plausibility that novel coronaviruses may also spill over to new wildlife hosts through

196 infected faecal matter accidentally entering the natural aquatic environment; this potential

197 virus reservoir could enable future resurgence in the human population.

\section{Supplementary}

200 Data files are provided for the viable viral counts (viral_counts.xIsx) and relative risk data 201 (relative_risk.xlsx).

\section{Acknowledgements}

204 JDS, KZ and RD were partially supported by the European Union Marie Curie Innovative 205 Training Network AquaSense (grant H2020-MSCA-ITN-2018-813680). RD was partially 206 supported through Engineering and Physical Science Research Council (EPSRC) 207 Engineering Fellowship for Growth (grant EP/R029644/1). JDS and TH were partially 208 supported by the European Space Agency project OceanSODA (grant 4000125955/18/l209 BG).

\section{Author contributions}

212 JDS, KZ, RD and TH developed the initial ideas. JDS, KZ, TH, MM, KU and LM developed 213 the methods. IA provided computing facilities. All authors contributed to the writing of the manuscript. 
medRxiv preprint doi: https://doi.org/10.1101/2020.06.17.20133504; this version posted June 20, 2020. The copyright holder for this preprint (which was not certified by peer review) is the author/funder, who has granted medRxiv a license to display the preprint in perpetuity.

It is made available under a CC-BY 4.0 International license .

\section{Methods}

\section{Risk from wastewater spillage between countries}

217 The relative risk of SARS CoV-2 from waste water systems is calculated by using a

218 modified version of equations 1 and 2 from ${ }^{13}$, given as

$219 \quad H_{c}=\frac{1}{V_{w w, c} D F_{c}}$

where $V_{w w, c}$ is the per capital daily volume of domestic water usage for country $c$, and $D_{c}$

221 is the dilution factor downloaded from ${ }^{13}$ supplemental table 1 and supplemental table 2 ,

222 respectively. Normalising $\mathrm{H}_{\mathrm{c}}$ across all country median DF values provides the between

223 country relative risk of water borne infection due to the viral load in a river following a

224 sewage effluent spill (shown in figures $1 \mathrm{~b}$ and $1 \mathrm{c}$ ).

The number of infectious virus copies in the water system as a result of a waste water spill or leak is calculated by multiplying $\mathrm{H}_{\mathrm{c}}$ by the number of infectious viruses in faeces generated by the infectious proportion of a county's population, $\mathrm{C}_{\text {inf,c }}$. This is calculated using

$C_{\text {inf }, \mathrm{c}}=\frac{V_{\text {faeces }} C_{\text {faeces }} P_{C}}{I}$

231 where $V_{\text {faeces }}$ is the volume of faeces generated (litres, $L$, per capita per day), $C_{\text {faeces }}$ is the 232 number of viral RNA copies in faecal matter $\left(\mathrm{L}^{-1}\right), \mathrm{P}_{\mathrm{c}}$ is the proportion of the population of 233 country $c$ that have active infections, and $/$ is the ratio of viral RNA copies to viable 234 (infectious) virus.

235 We note that measured wastewater viral counts in Paris on the $9^{\text {th }}$ April were $3.1 \times 10^{6}$ 236 genome copies $\mathrm{L}^{-1}$ with 82,000 active cases ${ }^{19}$, whereas using our (albeit country specific) 237 method gives the estimate of $1.3 \times 10^{6}$ genome copies $L^{-1}$, which is within the correct order 238 of magnitude (this calculation used the same number of active cases). 
medRxiv preprint doi: https://doi.org/10.1101/2020.06.17.20133504; this version posted June 20, 2020. The copyright holder for this preprint (which was not certified by peer review) is the author/funder, who has granted medRxiv a license to display the preprint in perpetuity.

It is made available under a CC-BY 4.0 International license .

240 To calculate $C_{\text {faeces }}$ we assumed a log-normal distribution and calculated the expected

241 value using the mean and standard deviation from ${ }^{12}$ using the standard equation:

$242 C_{\text {faeces }}=\exp \left(\ln \left(10^{\mu}\right)+0.5\left(\ln \left(10^{\sigma}\right)^{2}\right)\right)$

243 Where $\mu$ is the sample mean and $\sigma$ is the sample standard deviation of the log normal distribution. ${ }^{12}$ state that $\mu$ of the distribution is $5.22 \log _{10}$ copies $\mathrm{ml}^{-1}$ and $\sigma=1.86 \log _{10}$ copies $\mathrm{ml}^{-1}$ which results in an expected $\mathrm{C}_{\text {faeces }}$ concentration within the sewage effluent of 1595.9 million copies $\mathrm{ml}^{-1}$. $\mathrm{V}_{\text {faeces }}$ is the mean daily volume of faeces generated per person ( $0.149 \mathrm{~kg}$, from table 3 of ${ }^{26}$ and assuming faeces has a density approximately equal to water ${ }^{27}$. Note we used the 'rich country' value from ${ }^{26}$ because the RT-PCR data ${ }^{12}$ that we use to estimate $\mathrm{C}_{\text {faeces }}$ was measured from samples collected in Germany. The prevalence data, $\mathrm{P}_{\mathrm{c}}$, were calculated by subtracting the number of recovered and number

PCA does not distinguish between infectious virus and damaged/destroyed non-infectious virus. Therefore, to estimate the number of viable (infectious) virus copies, we used literature on the ratio of infectious adenovirus copies to genome copies in raw sewage (eg Rodríguez et al., 2013) wastewater discharged into rivers ${ }^{17}$. These estimates varied over four orders of magnitude, and as such we selected high $\left(10^{-1}\right)$, medium $\left(10^{-2}\right)$ and low $\left(10^{-}\right.$

${ }^{3}$ ) estimates (which equate to $10 \%, 1 \%$ and $0.1 \%$ proportion of viable versus within the

261 The expected number of copies of infectious virus resulting from a sewage spill into a river, 262 lake or coastal region for a given country can therefore be calculated as and were known to rely upon reservoirs for drinking water ${ }^{28}$. Long-term statistical mean 
medRxiv preprint doi: https://doi.org/10.1101/2020.06.17.20133504; this version posted June 20, 2020. The copyright holder for this preprint (which was not certified by peer review) is the author/funder, who has granted medRxiv a license to display the preprint in perpetuity.

It is made available under a CC-BY 4.0 International license .

water temperature, needed to calculate virus survivability, was calculated from a climate quality global lake temperature dataset (see below). Temperature values for each country were the countrywide mean lake temperature within a rectangular box matching a simplified country outline. The dilution factors reported in ${ }^{13}$ can vary by several orders of magnitude and were deemed to provide the major source of uncertainty in the calculation. Therefore, the $\mathrm{C}_{\text {spill,c }}$ viral loadings given by the $25^{\text {th }}$ percentile dilution, median dilution and $75^{\text {th }}$ percentile dilution values are all presented. With high, medium and low estimates for I, this results in nine estimates of $\mathrm{C}_{\text {spill }}$ for each country.

The long-term statistical mean global lake water temperature climatology was constructed using the $0.05^{\circ} \times 0.05^{\circ}$ daily resolution GloboLakes v4 data set ${ }^{29}$ which covers 1996 to 2016. Mean temperature was calculated for each calendar month across all years producing 12 monthly mean datasets with a $0.05^{\circ} \times 0.05^{\circ}$ gridded resolution. Uncertainty terms were propagated by assuming random errors were independent and normally distributed, and using standard error propagation methods. The resulting uncertainty term combines the original uncertainty in measurement and optimum interpolation with the spatial/temporal uncertainty of the resampled monthly average, for each grid cell.

The concentration of SARS-CoV-2 virus needed for infection is not known. ${ }^{30}$ provides $10^{3}$ copies for influenza. The Infectious dose for SARS-CoV-2 is likely significantly lower because ${ }^{31}$ ranks influenza as "very high infective dose" and SARS-CoV-2 as "low". We therefore use a value of 100 copies as a concentration that could result in infection.

\section{A combined uncertainty budget for equation 4 was calculated using standard uncertainty} propagating methods and estimates of the uncertainties of each input dataset. Uncertainty components (and their values) were domestic water usage $( \pm 10 \%)$, population size $( \pm 1 \%)$, 
medRxiv preprint doi: https://doi.org/10.1101/2020.06.17.20133504; this version posted June 20, 2020. The copyright holder for this preprint (which was not certified by peer review) is the author/funder, who has granted medRxiv a license to display the preprint in perpetuity.

It is made available under a CC-BY 4.0 International license .

292 number of active cases $( \pm 20 \%)$, mass of faeces generated per capita per day $(0.095 \mathrm{~kg}$,

293 see table 3 of ${ }^{26}$, mean number of viral genome copies in faeces $\left(3.54 \times 10^{12}\right)$ and density of

294 faeces was not included in the uncertainty analysis. This resulted in a combined

295 uncertainty budget of $\pm 68 \%$ copies $\mathrm{ml}^{-1}$. It is important to note that this value does not

296 include uncertainty in the dilution factors or the ratio of viral genome copies to infectious

297 virus. Instead, the $\mathrm{C}_{\text {inf }}$ calculation was repeated for high, medium and low values of these

298 parameters.

\section{Temperature dependent survival}

301 As reported in ${ }^{3}$, the virus concentration in water follows an exponential decay, with its 302 half-life decreasing with decreasing temperature and the $\mathrm{pH}$ control of half life is very small over the $\mathrm{pH}$ range of 3-10 (which encompasses the range found in natural freshwater and marine systems). Based on the in vitro data presented in ${ }^{3}$, the following empirical model was derived to describe virus concentration reduction factor due to the temperaturedependent die-off:

$$
r=10^{0.05 T\left[{ }^{\circ} \mathrm{C}\right]-1.32}
$$

Where $\mathrm{C}_{0}$ is initial virus concentration (copies $\mathrm{ml}^{-1}$ ), $n(t)$ is virus concentration after time $t$ (days) and $r$ is 24 hour survival factor due to temperature $T$ driven die off. This model fit to the in vitro data gives a root mean square difference (RMSD) of $\pm 1 \%$ for water at $4^{\circ} \mathrm{C}$ which increases to $\pm 7.5 \%$ at $22^{\circ} \mathrm{C}$. When considering temperature controlled survival in

313 the waste water system, $\mathrm{C}_{\mathrm{ww}, \mathrm{c}}$ becomes the value used for the initial viral load $\mathrm{C}_{0}$ following 314 a sewage effluent spill. As noted in ${ }^{5,12}$, the viral load follows a heavy-tailed distribution 315 with the majority of patients shedding around $10^{5}$ copies $\mathrm{ml}^{-1}$ ) but some having viral loads as high as $10^{12}$ copies $\mathrm{ml}^{-1}$. This results in the super-spreader problem where a tiny proportion of the infected population can become responsible for contributing a majority of 
medRxiv preprint doi: https://doi.org/10.1101/2020.06.17.20133504; this version posted June 20, 2020. The copyright holder for this preprint (which was not certified by peer review) is the author/funder, who has granted medRxiv a license to display the preprint in perpetuity.

It is made available under a CC-BY 4.0 International license .

318 viral load in the wastewater. For a large infected population, this approach allows robust

319 statistical modeling of viral load. However, in case of smaller communities with low number

320 of infections, the actual viral load could be severely underestimated if a super-spreader is

321 present within the population.

Whale filtering calculation

324 The example volume flow rate through the mouth of a medium sized Bowhead whale

325 whilst feeding was provided by ${ }^{32}$ ) A flow rate of $5.65 \mathrm{~m}^{3} \mathrm{~s}^{-1}$ is given for a $15 \mathrm{~m}$ whale

326 (mouth pressure of $-1768 \mathrm{~Pa}$ at a $4 \mathrm{~km} \mathrm{~h}^{-1}$ foraging speed, assuming an oral opening of

$3275.09 \mathrm{~m}^{2}$ with an opening radius $=1.27 \mathrm{~m}$ ). Assuming a low viral concentration of 1 copies

328 per ml$l^{-1}$, which equates to 1000 copies $\mathrm{l}^{-1} .5 .65 \mathrm{~m}^{3} \mathrm{~s}^{-1}$ equates to $5650 \mathrm{~L} \mathrm{~s}^{-1}$. The dosage

329 per second as the whale swims during feeding is given by 1000 (copies $\left.\mathrm{L}^{-1}\right) \times 5650\left(\mathrm{~L} \mathrm{~s}^{-1}\right)$

$330=5.65$ million copies $\mathrm{s}^{-1}$.

\section{References}

3331. Lai, C. C., Shih, T. P., Ko, W. C., Tang, H. J. \& Hsueh, P. R. Severe acute

334 respiratory syndrome coronavirus 2 (SARS-CoV-2) and coronavirus disease-2019

335 (COVID-19): The epidemic and the challenges. International Journal of Antimicrobial

336 Agents 55, 105924 (2020). doi:10.1016/j.ijantimicag.2020.105924

3372. Rodino, K. G. et al. Evaluation of saline, phosphate buffered saline and minimum

338 essential medium as potential alternatives to viral transport media for SARS-CoV-2

339 testing. Journal of clinical microbiology (2020). doi:10.1128/JCM.00590-20

3403. Chin, A. et al. Stability of SARS-CoV-2 in different environmental conditions.

341 medRxiv 2020.03.15.20036673 (2020). doi:10.1101/2020.03.15.20036673

3424. Xiao, F. et al. Infectious SARS-CoV-2 in Feces of Patient with Severe COVID-19.

343 Emerg. Infect. Dis. 26, (2020). doi:10.3201/eid2608.200681

3445. Wölfel, R. et al. Virological assessment of hospitalized patients with COVID-2019.

$345 \quad$ Nature 581, 465-469 (2020). doi:10.1038/s41586-020-2196-x

3466. Lavezzo, E. et al. Suppression of COVID-19 outbreak in the municipality of Vo, Italy.

347 medRxiv 2020.04.17.20053157 (2020). doi:10.1101/2020.04.17.20053157 
medRxiv preprint doi: https://doi.org/10.1101/2020.06.17.20133504; this version posted June 20, 2020. The copyright holder for this preprint (which was not certified by peer review) is the author/funder, who has granted medRxiv a license to display the preprint in perpetuity. It is made available under a CC-BY 4.0 International license .

3487. La Rosa, G. et al. First detection of SARS-CoV-2 in untreated wastewaters in Italy. 349 Sci. Total Environ. 736, 139652 (2020). doi:10.1016/j.scitotenv.2020.139652

3508. Ahmed, W. et al. First confirmed detection of SARS-CoV-2 in untreated wastewater 351 in Australia: A proof of concept for the wastewater surveillance of COVID-19 in the 352 community. Sci. Total Environ. 728, 138764 (2020).

353 doi:10.1016/j.scitotenv.2020.138764

3549. Gundy, P. M., Gerba, C. P. \& Pepper, I. L. Survival of Coronaviruses in Water and 355 Wastewater. Food Environ. Virol. 1, 10-14 (2009). doi:10.1007/s12560-008-9001-6

35610. Amirian, E. S. Potential fecal transmission of SARS-CoV-2: Current evidence and 357 implications for public health. Int. J. Infect. Dis. 95, 363-370 (2020).

358 doi:10.1016/j.ijid.2020.04.057

35911. Olds, H. T. et al. High levels of sewage contamination released from urban areas 360 after storm events: A quantitative survey with sewage specific bacterial indicators. 361 PLOS Med. 15, e1002614 (2018). doi:10.1371/journal.pmed.1002614

36212. Jones, T. C. et al. An analysis of SARS-CoV-2 viral load by patient age. Report, 363 (2020).

36413. Keller, V. D. J., Williams, R. J., Lofthouse, C. \& Johnson, A. C. Worldwide estimation of river concentrations of any chemical originating from sewage-treatment plants using dilution factors. Environ. Toxicol. Chem. 33, 447-452 (2014).

367 doi:10.1002/etc.2441

36814. McBride, G. B., Stott, R., Miller, W., Bambic, D. \& Wuertz, S. Discharge-based 369 QMRA for estimation of public health risks from exposure to stormwater-borne 370 pathogens in recreational waters in the United States. Water Res. 47, 5282-5297 $371 \quad$ (2013). doi:10.1016/j.watres.2013.06.001

37215. La Rosa, G., Bonadonna, L., Lucentini, L., Kenmoe, S. \& Suffredini, E. Coronavirus in water environments: Occurrence, persistence and concentration methods - A scoping review. Water Res. 179, 115899 (2020). doi:10.1016/j.watres.2020.115899

37516. Rodríguez, R. A., Polston, P. M., Wu, M. J., Wu, J. \& Sobsey, M. D. An improved infectivity assay combining cell culture with real-time PCR for rapid quantification of 377 human adenoviruses 41 and semi-quantification of human adenovirus in sewage.

$378 \quad$ Water Res. 47, 3183-3191 (2013). doi:10.1016/j.watres.2013.03.022

37917. Sedji, M. I. et al. Quantification of human adenovirus and norovirus in river water in 380 the north-east of France. Environ. Sci. Pollut. Res. 25, 30497-30507 (2018).

381 doi:10.1007/s11356-018-3045-4

38218. Zaneti, R. N. et al. QMRA of SARS-CoV-2 for workers in wastewater treatment 383 plants. medRxiv 2020.05.28.20116277 (2020). doi:10.1101/2020.05.28.20116277

38419. Wurtzer, S. et al. Evaluation of lockdown impact on SARS-CoV-2 dynamics through 385 viral genome quantification in Paris wastewaters. medRxiv 2020.04.12.20062679 386 (2020). doi:10.1101/2020.04.12.20062679 
medRxiv preprint doi: https://doi.org/10.1101/2020.06.17.20133504; this version posted June 20, 2020. The copyright holder for this preprint (which was not certified by peer review) is the author/funder, who has granted medRxiv a license to display the preprint in perpetuity. It is made available under a CC-BY 4.0 International license .

38720. Damas, J. et al. Broad Host Range of SARS-CoV-2 Predicted by Comparative and 388 Structural Analysis of ACE2 in Vertebrates. bioRxiv 2020.04.16.045302 (2020).

389 doi:10.1101/2020.04.16.045302

39021. Rusiñol, M. et al. Evidence of viral dissemination and seasonality in a Mediterranean river catchment: Implications for water pollution management. J. Environ. Manage. 159, 58-67 (2015). doi:10.1016/j.jenvman.2015.05.019

39322. WHO. Water, sanitation, hygiene, and waste water management for the COVID-19 virus: interim guidance. (2020).

39523. Derraik, J. G. B., Anderson, W. A., Connelly, E. A. \& Anderson, Y. C. Rapid evidence summary on SARS-CoV-2 survivorship and disinfection, and a reusable PPE protocol using a double-hit process. medRxiv (2020). doi:10.1101/2020.04.02.20051409

39924. Wang, X.-W. et al. Study on the resistance of severe acute respiratory syndrome400 associated coronavirus. J. Virol. Methods 126, 171-177 (2005).

401 doi:10.1016/j.jviromet.2005.02.005

40225. Huyvaert, K. P. et al. Freshwater Clams As Bioconcentrators of Avian Influenza 403 Virus in Water. Vector-Borne Zoonotic Dis. 12, 904-906 (2012).

404 doi:10.1089/vbz.2012.0993

40526. Rose, C., Parker, A., Jefferson, B. \& Cartmell, E. The Characterization of Feces and 406 Urine: A Review of the Literature to Inform Advanced Treatment Technology. Crit.

407 Rev. Environ. Sci. Technol. 45, 1827-1879 (2015).

408 doi:10.1080/10643389.2014.1000761

40927. Penn, R., Ward, B. J., Strande, L. \& Maurer, M. Review of synthetic human faeces 410 and faecal sludge for sanitation and wastewater research. Water Res. 132, 222-240 411 (2018). doi:10.1016/j.watres.2017.12.063

41228. White, W. R. World water: resources, usage and the role of man made reservoirs, $413 \quad F R / R 0012$. (2019).

41429. Carrea, L. \& Merchant, C. J. GloboLakes: Lake Surface Water Temperature (LSWT) v4.0 (1995-2016). Cent. Environ. Data Anal. (2019).

416 doi:10.5285/76a29c5b55204b66a40308fc2ba9cdb3

41730. Nikitin, N., Petrova, E., Trifonova, E. \& Karpova, O. Influenza Virus Aerosols in the $418 \quad$ Air and Their Infectiousness. Adv. Virol. (2014). doi:10.1155/2014/859090

41931. Lee, P.-I. \& Hsueh, P.-R. Emerging threats from zoonotic coronaviruses-from SARS 420 and MERS to 2019-nCoV. J. Microbiol. Immunol. Infect. 53, 365-367 (2020).

421 doi:10.1016/j.jmii.2020.02.001

42232. Werth, A. J. Models of hydrodynamic flow in the bowhead whale filter feeding 